\title{
ANALISIS FAKTOR-FAKTOR YANG MEMPENGARUHI EKSPOR KOMODITAS TEH INDONESIA
}

\author{
Supriani Sidabalok \\ Universitas Muslim Nusantara Al-Washliyah \\ Kampus A: Jl. Garu II No. 93, Kampus B: Jl. Garu II No.2 \\ supriani3@gmail.com
}

\begin{abstract}
Abstrak
Penelitian ini bertujuan untuk: (1) untuk menganalisis bagaimana pengaruh harga ekspor teh Indonesia di luar negeri terhadap volume ekspor teh Indonesia, (2) untuk menganalisis bagaimana pengaruh nilai tukar rupiah terhadap dolar AS terhadap volume ekspor teh Indonesia, (3) untuk menganalisis bagaimana pengaruh pendapatan negara pengimpor teh terbesar terhadap volume ekspor teh Indonesia, dan (4) untuk menganalisis bagaimanapengaruh harga kopi sebagai barang substitusi dari teh terhadap volume ekspor teh Indonesia.Data yang digunakan adalah time series dari tahun 2002 sampai 2013 dan data cross section dari 5 negara pengimpor teh Indonesia yaitu Rusia, Pakistan, Malaysia, Jerman, dan AS. Metode analisis yang digunakan adalah model regresi Ordinary Least Square-Pooled Data dengan bantuan software Eviews versi 6.0. Hasil regresi menunjukkan bahwa variabel nilai tukar (EX), harga ekspor teh $(P L)$, pendapatan nasional negara pengimpor $(P D B)$, dan harga kopi $(P C)$ secara bersama-sama mampu menjelaskan variasi atau perubahan variabel volume ekspor teh Indonesia sebesar 86,36\% sedangkan sisanya 13,64\% dijelaskan oleh variabel lain yang tidak dimasukkan dalam model estimasi.
\end{abstract}

Kata kunci: ekspor teh, nilai tukar, harga ekspor teh, PDB, harga kopi

\begin{abstract}
This study aims to: (1) to analyze how the effect of export prices of Indonesian tea abroad to the export volume of Indonesian tea, (2) to analyze how the effect of rupiah exchange rate against the US dollar on the export volume of Indonesian teas, (3) to analyze how (4) to analyze how the price of coffee as a substitute of tea to tea export volume Indonesia.Data used time series from 2002 to 2013 and cross section data from 5 countries importers of Indonesian tea are Russia, Pakistan, Malaysia, Germany, and USA. The method of analysis used is the Ordinary Least Square-Pooled Data regression model with the help of Eviews version 6.0 software. The regression results show that the exchange rate (EX), tea export price (PL), national income of importing country (GDP), and the price of coffee (PC) are together able to explain variation or change of variable export volume of Indonesian tea 86,36 \% while the remaining $13.64 \%$ is explained by other variables not included in the estimation model.
\end{abstract}

Keywords: export of tea, exchange rate, tea export price, GDP, coffee price 


\section{PENDAHULUAN}

Kegiatan perdagangan antarnegara adalah hal yang tidak bisa dipisahkan dalam era globalisasi saat ini.Ketergantungan antarnegara semakin tinggi dalam pemenuhan kebutuhan dalam negeri, sehingga masing-masing negara memasarkan produk unggulannya di pasar global yang dikenal dengan kegiatan ekspor dan impor (Bustami dan Hidayat, 2013).

Di Indonesia secara umum jenis ekspor dibagi dua yaitu ekspor migas dan non migas.Sektor non migas merupakan salah satu sumber pendapatan devisa negara. Sektor non migas dibagi menjadi tiga, antara lain: (i) sektor industri, (ii) sektor pertambangan, dan (iii) sektor pertanian. Salah satu sub sektor pertanian adalah perkebunan. Salah satu komoditas perkebunan yang banyak dikembangkan di Indonesia adalah komoditas teh.

Banyaknya produksi teh dalam negeri serta faktor lainnya menyebabkan pemasaran teh tidak hanya di dalam negeri tapi juga mancanegara.Sehingga teh merupakan salah satu komoditas hasil perkebunan Indonesia yang banyak diekspor. Teh sebagai tanaman perkebunan merupakan salah satu komoditas yang menarik bagi banyak negara terutama negara berkembang, karena perkebunan teh memberi kesempatan kerja yang cukup tinggi sehingga dapat mengurangi jumlah pengangguran, meningkatkan pendapatan masyarakat dan pada akhirnya dapat menghasilkan devisa yang sangat diperlukan bagi pembangunan nasional.

Sebagian besar (70\%) teh Indonesia diekspor sehingga Indonesia tercatat menjadi urutan kelima eksportir teh terbesar di dunia setelah Kenya, Sri Lanka, India dan Vietnam. Namun harga teh Indonesia di pasar internasional masih begitu rendahyaitu diekspor dalam keadaan mentah, hanya dihargai US\$ 1 per kilogram.

Sangat disayangkan memang, ditengah geliat pertumbuhan permintaan teh dunia yang semakin menggembirakan, produktivitas teh dalam negeri justru mengalami kondisi yang memprihatinkan. Padahal jika dikelola dengan baik, sektor ini akan mampu mendongkrak peningkatan devisa negara juga pengurangan angka pengangguran yang hari ini menjadi masalah serius bangsa.

Kondisi riilnya adalah pasar ekspor teh masih terbuka lebar.Terlihat dari kurangnya pasokan teh dunia yang menyebabkan kelebihan permintaan sebesar 13 ribu ton per tahun.Diperkirakan dalam tahuntahun berikutnya permintaan teh dunia dapat meningkat dan kondisi ini harus diikuti dengan peningkatan penawaran ekspor dari negara-negara produsen teh. Hal ini merupakan peluang bagi Indonesia untuk meningkatkan penawaran ekspor teh ke pasar dunia.

\subsection{Perumusan Masalah}

Berdasarkan latarbelakang diatas maka rumusan masalah dari penelitian ini adalah bagaimana pengaruh faktor-faktor seperti harga ekspor teh, nilai tukar rupiah terhadap dolar AS, pendapatan negara pengimpor teh terbesar (Rusia, Malaysia, Pakistan, Jerman, Amerika Serikat) dan harga kopi sebagai barang substitusi dari teh mempengaruhi ekspor teh Indonesia. 


\subsection{Tujuan Penelitian}

Berdasarkan rumusan masalah, maka tujuan dari penelitian ini adalah untuk menganalisis bagaimana pengaruh faktor-faktor seperti harga ekspor teh, nilai tukar rupiah terhadap dolar AS, pendapatan negara pengimpor teh terbesar (Rusia, Malaysia, Pakistan, Jerman, Amerika Serikat) dan harga kopi sebagai barang substitusi dari teh mempengaruhi ekspor teh Indonesia.

\section{METODE}

\subsection{Ruang Lingkup Penelitian}

Penelitian ini menganalisis faktor-faktor yang mempengaruhi jumlah ekspor teh Indonesia ke-5 negara pengimpor teh terbesar, dari tahun 2002 sampai dengan tahun 2013. Adapun faktor-faktor yang diduga mempengaruhi jumlah ekspor teh Indonesia di pasar dunia adalah harga ekspor teh, nilai tukar rupiah terhadap dolar AS, pendapatan negara pengimpor teh terbesar (Rusia, Malaysia, Pakistan, Jerman, Amerika Serikat) dan harga kopi sebagai barang substitusi dari teh.

\subsection{Jenis dan Sumber Data}

Jenis data yang digunakan dalam penelitian ini adalah data sekunder, yaitu data panel yaitu gabungan antara data time series dan cross section dari tahun 2002 sampai dengan tahun 2013 dan diolah menggunakan software Eviews 6.0.

Data panel merupakan kombinasi antara data deret/runtut waktu dan data seksi silang untuk dapat dianalisis melalui model regresi data panel. Diharapkan melalui pengumpulan data dari berbagai lembaga dan instansi terkait di atas, dalam penelitian ini dapat dibentuk suatu balanced panel, yakni setiap unit data seksi silang mempunyai jumlah observasi runtun waktu yang sama.

\subsection{Model Penelitian}

Dalam penelitian ini yang menjadi variabel dependennya adalah volume ekspor teh Indonesia, sedangkan variabel independennya adalah harga ekspor teh Indonesia di pasar dunia, nilai tukar rupiah terhadap US\$, PDB negara pengimpor teh Indonesia terbesar, dan harga barang substitusi teh (yaitu kopi) dunia.

Model fungsi produksi CobbDauglas yang akan dijadikan sebagai model penelitian dituliskan dalam fungsi matematis sebagai berikut: $X_{i 1}=\mathrm{f}\left(P_{i 1}, E_{i 1}, P \quad{ }_{i 1}, P_{i 1}\right)$

\section{HASIL DAN PEMBAHASAN}

Hasil penelitian dengan menggunakan Eviews versi 6.0 ditunjukkan pada tabel berikut.

Tabel 4.1. Hasil Estimasi FaktorFaktor Yang Mempengaruhi Ekspor Teh Indonesia

\begin{tabular}{|c|c|c|c|c|}
\hline $\begin{array}{l}\text { Vari } \\
\text { abel }\end{array}$ & $\begin{array}{c}\text { Koefi } \\
\text { sien } \\
\text { Esti } \\
\text { masi }\end{array}$ & $\begin{array}{l}\text { t- } \\
\text { stati } \\
\text { stik }\end{array}$ & $\begin{array}{c}\text { Pro } \\
\text { b. }\end{array}$ & $\begin{array}{c}\text { Signifi } \\
\text { kansi }\end{array}$ \\
\hline EX & $\begin{array}{c}0.465 \\
047\end{array}$ & $\begin{array}{c}3.11 \\
7922\end{array}$ & $\begin{array}{c}0.0 \\
030\end{array}$ & $S$ \\
\hline PC & $\begin{array}{c}0.133 \\
667\end{array}$ & $\begin{array}{r}1.76 \\
6103\end{array}$ & $\begin{array}{c}0.0 \\
834\end{array}$ & $S$ \\
\hline PDB & $\begin{array}{c}0.566 \\
553\end{array}$ & $\begin{array}{l}4.85 \\
4003\end{array}$ & $\begin{array}{c}0.0 \\
000\end{array}$ & $S$ \\
\hline PL & $\begin{array}{c}- \\
0.346 \\
716\end{array}$ & $\begin{array}{c}- \\
2.87 \\
8560\end{array}$ & $\begin{array}{c}0.0 \\
058\end{array}$ & $S$ \\
\hline $\begin{array}{l}\text { Kons } \\
\text { tanta }\end{array}$ & $\begin{array}{c}- \\
1.915 \\
490\end{array}$ & $\begin{array}{c}- \\
1.23 \\
7601\end{array}$ & $\begin{array}{c}0.2 \\
215\end{array}$ & $\mathrm{~S}$ \\
\hline
\end{tabular}

Sumber: Eviews 6.0 
Keterangan: $R^{2}=0.863570 ; \mathrm{F}$-stat $=$ 40.35237; Prob. $=0.000000 ; \mathrm{DW}=$ 1.370605; $\mathrm{S}=$ Signifikan

\subsection{Interpretasi Hasil}

1. Pengaruh Nilai Tukar Terhadap Jumlah Ekspor Teh Indonesia

Dari hasil estimasi diketahui bahwa variabel total nilai tukar (EX) mendapatkan statistik uji $\mathrm{t}=$ 3.117922 dengan signifikansi 0.0030, hal ini berarti bahwa parameter antara variabel nilai tukar dengan jumlah ekspor teh Indonesia menghasilkan nilai signifikansi sebesar 0.0030 atau dengan tingkat kepercayaan $99 \%$.

Dari hasil estimasi persamaan regresi tersebut diperoleh pengaruh positif perubahan nilai tukar terhadap jumlah ekspor teh Indonesia dengan nilai koefisiensi sebesar 0.465047 yang berarti jika nilai tukar rupiah terhadap dolar penurunan (depresiasi) sebesar 1\% maka jumlah ekspor teh Indonesia secara rata-rata akan meningkat sebesar $0,47 \%$ cateris paribusdapat diterima. Tanda koefisien sama dengan yang diharapkan dan hal tersebut sesuai teori dan penelitian terdahulu dan membuktikan hipotesis bahwa terdapat pengaruh positif perubahan nilai tukar terhadap jumlah ekspor teh Indonesia.

2. Pengaruh Harga Barang Substitusi (Kopi) Terhadap Jumlah Ekspor Teh Indonesia

Dari hasil estimasi diketahui bahwa variabel total harga barang substitusi (kopi) mendapatkan statistik uji $\mathrm{t}=1.766103$ dengan signifikansi 0.0834 , hal ini berarti bahwa parameter antara variabel harga barang substitusi dari teh yaitu kopi (PC) dengan jumlah ekspor teh Indonesia menghasilkan nilai signifikansi sebesar 0.0834 atau dengan tingkat kepercayaan $90 \%$.

Dari hasil estimasi persamaan regresi tersebut juga diperoleh pengaruh positif harga barang substitusi dari kopi yaitu teh terhadap jumlah ekspor teh Indonesia sebesar 0.133667 yang berarti jika harga kopi meningkat $1 \%$ maka jumlah ekspor teh Indonesia secara rata-rata akan meningkat sebesar $0,13 \%$, cateris paribusdapat diterima. Tanda koefisien sesuai dengan yang diharapkan dan hal tersebut sesuai dengan teori dan penelitian terdahulu, dan membuktikan hipotesis bahwa terdapat hubungan positif antara harga kopi sebagai barang substitusi dari teh terhadap jumlah ekspor teh Indonesia.

\section{Pengaruh Pendapatan Nasional Negara Pengimpor Terhadap Jumlah Ekspor Teh Indonesia}

Dari hasil estimasi diketahui bahwa variabel pendapatan nasional negara pengimpor (PDB) mendapatkan statistik uji $\mathrm{t}=$ 4.854003 dengan signifikansi 0.0000 , hal ini berarti bahwa parameter antara variabel pendapatan nasional negara pengimpor dengan jumlah ekspor teh Indonesia yang dibentuk menghasilkan nilai signifikansi sebesar 0.0000 atau dengan tingkat kepercayaan $99 \%$.

Dari hasil estimasi persamaan regresi tersebut juga diperoleh pengaruh pendapatan nasional negara pengimpor (PDB) terhadap jumlah ekspor teh Indonesia sebesar 0.566553 yang berarti jika jumlah PDB meningkat $1 \%$ maka jumlah ekspor teh Indonesia akan meningkat sebesar $0,57 \%$ cateris paribus dapat diterima. Tanda koefisien sesuai dengan yang diharapkan dan hal tersebut sesuai dengan teori dan 
membuktikan hipotesis bahwa terdapat pengaruh pendapatan nasional negara pengimpor (PDB) terhadap jumlah ekspor teh Indonesia (Y) diterima.

\section{Pengaruh Harga Teh Indonesia di Luar Negeri Terhadap Jumlah Ekspor Teh Indonesia}

Dari hasil estimasi diketahui bahwa variabel harga teh Indonesia di luar negeri mendapatkan statistik uji $\mathrm{t}=-2.878560$ dengan signifikansi 0.0058 atau dengan tingkat kepercayaan $99 \%$.

Dari hasil estimasi persamaan regresi tersebut juga diperoleh pengaruh negatif harga teh Indonesia di luar negeri terhadap jumlah ekspor teh Indonesia sebesar -0.346716 yang berarti jika harga teh Indonesia di luar negeri meningkat sebesar $1 \%$ maka jumlah ekspor teh Indonesia akan menurun secara rata-rata sebesar $0,35 \%$, cateris paribus dapat diterima. Tanda koefisien sesuai dengan yang diharapkan dan hal tersebut sesuai dengan teori dan membuktkan hipotesis bahwa terdapat pengaruh negatif antara harga teh Indonesia di luar negeri terhadap jumlah ekspor teh Indonesia diterima.

\section{KESIMPULAN}

dan pembahasan yang telah dilakukan dalam penelitian ini maka dapat diambil kesimpulan sebagai berikut:

1. Variabel nilai tukar, pendapatan nasional negara pengimpor, dan harga kopi sebagai barang substitusi teh berpengaruh positif dan siginifikan terhadap jumlah ekspor teh Indonesia ke-5 negara pengimpor teh terbesar (Rusia,
Pakistan, Malaysia, Jerman, dan AS).

2. Variabel harga ekspor teh Indonesia berpengaruh negatif dan signifikan terhadap jumlah ekspor teh Indonesia ke-5 negara pengimpor teh terbesar (Rusia, Pakistan, Malaysia, Jerman, dan AS).

3. Nilai koefisien regresi maksimum terjadi pada variabel pendapatan nasional negara pengimpor (PDB) yaitu sebesar 0.566553. Yang artinya jika dibandingkan dengan tiga variabel bebas lainnya, variabel PDB memberi pengaruh yang paling besar.

4. Nilai koefisien regresi minimum terjadi pada variabel harga kopi sebagai barang substitusi teh (PC) yaitu sebesar 0.133667. Yang artinya jika dibandingkan dengan tiga variabel bebas lainnya, variabel PC memberi pengaruh yang paling kecil.

\section{DAFTAR PUSTAKA}

Aggraini, Dewi. 2006. Faktor-Faktor Yang Mempengarhi Permintaan Ekspor Kopi Indonesia Dari Amerika Serikat. Tesis tidak diterbitkan. Semarang: Program Pascasarjana Universitas Diponegoro.

Ananta, A. 1987.Landasan Ekonometrika. Jakarta: Gramedia. Anthony, Peter, and Richard. 2012. The Impact of Macroeconomic Variables on Non-Oil.

Bustami, Budi Ramanda dan Paidi Hidayat. 2013. Analisis Daya Saing Produk Ekspor Provinsi Sumatera Utara. Jurnal Ekonomi dan Keuangan.[jurnal]. Vol.1, No.2, hal:56-71., 1986-2010. Journal of Economics and 
SustainableDevelopment 3(5): hal: 27-41.

Deliarnov. 1995. Pengantar Ekonomi Makro. Jakarta: Bina Grafika.

Febriyenti, Mega dkk. 2013. FaktorFaktor Yang Mempengaruhi Cadangan Devisa dan Net Ekspor di Indonesia. Jurnal Kajian Ekonomi, Juli 2013 Volume II No.03.

Gujarati, Damodar. 2003. Ekonometrika Dasar. (Drs. Ak.

Sumarno Zain, MBA (Terjemahan). Jakarta: Erlangga. Buku asli diterbitkan tahun 1978.

Insukindro, dkk. 2003. Modul Ekonometrik Dasar.Kerjasama Bank Indonesia dan Fakultas Ekonomi Universitas Gadjah Mada Jogjakarta. 
